\title{
About Advantages of Manager's Critical Thinking on Infrastructure of Town's Professional Musical Culture
}

\author{
An ability of critical thinking is not a happiness \\ guarantee yet; anyhow, it creates a fundament for \\ a more sense-bearing life.
}

\author{
Alexander Yakoupov \\ Russian State Specialized Academy of Arts \\ Moscow, Russia \\ E-mail: rgsai@mail.ru
}

\begin{abstract}
The cultural level of citizens largely depends on the infrastructure quality of city's professional culture institutions, on the access of city's population to artistic values and level of professionalism of the artistic workers who ensure the population's contact with these values. The forming a qualitative infrastructure of cultural institutions is one of the most important tasks of top-managers.
\end{abstract}

Keywords-Infrastructure of cultural institutions; artistic values; access to artistic values; creative enthusiasm

\section{To THE PRoblem OF SignificANCE OF A CULTURAL CITY INFRASTRUCTURE}

A residents' level of culture in any town depends much on a quality of an infrastructure of town's culture including quite a number of components. First of all, this is a presence of the following: professional institutions of culture ensuring population's consumption of cultural values; amateurish artistic groups that demonstrate extent of population's involvement into an active process of cultural values consumption; and also creative unions and public organizations promoting art works creation. Fundamental elements of this infrastructure functioning are an acting system of introducing of arts values to children and youth (music schools and art schools, amateurish creative unions, palaces and houses of culture, etc.) and extent of professional preparation of teams working in these organizations, their enthusiasm able to become contagious for others with their ideas and promote their development.

Despite of an absence of a managerial experience of my own, for an objective evaluation of Magnitogorsk's level of culture, I did not need conducting sociologic studies - It was enough to gaze at the infrastructure of the town's culture. Is it has been noted before, exactly this it what forms a townspeople cultural layer, which by its response, behavior and life style influence a society and makes it nobler and sets elevated spiritual priorities to it. This society layer would be pertinent to be compared with a fertile soil layer, the humus. Its presence allows holding a hope for a self-sustainability, a cycliciy of culture functioning, its spiritual maturity and its ability to natural reproduction. Upon the condition of this cultural layer existence, always, a society will need music and musicians, theaters and actors, pictures and artists, dances and choreographers - Just as in the nature: as far as the humus is present, there are forests, fields, bushes, and flowers, for life continuation of which, there is no need in an artificial fertilization. Whereas without it, the sight will be like in a desert. If a gardener takes care of his land lot, gardens bloom; but if a stop will be let happened for a while, the garden will be transformed into a desert - Everything will be needed to be started from the very beginning.

By 90-ies, Magnitogorsk's musicians came to a realization that in their activities on mass involvement into the musical culture, a formidable obstacle has formed - the low level of education of enlighteners' themselves. Shortages were deeply felt in area of people's serious musical upbringing, of possibility of influencing them in order to bring them a true sense of art values. There was a need in other personnel members - more educated, talented, having a high professional level.

Perhaps, the position of the music high school director inspired me among other reasons because earlier it was taken by a pre-eminent person. To become his successor was honorary. On the other hand, the responsibility grade was high. The new director was just as young as 28 - Much of young valiant fervor, enthusiasm, while as for an experience, there rather was felt a lack of it - Also knowledge was not enough. But there was an ardent desire to perform something great and meaningful for the town. So I worked indefatigably, 12-14 hours a day.

In that period of time, a statistics of a professional town's culture (if to put it mildly) was behindhand in impressive figures: there functioned seven music schools counting 300400 students each and one professional group, which was a state chapel choir. And that was it! There was no philharmonic hall. Instead, there existed so-called concertpop-music bureaus that could not perform a systematic work on serious music proliferation. On the other hand, musical amateurish groups were wide-spread: so in the system of the public education, there worked tens of school and club choirs, orchestras and ensembles of folk instruments, brass bands, pop-music groups - S.G. Eidinov being enchanted with educating ideas relied on them constantly in his activities 
devoted to town's musical life organization. In his initiative, in 1970, on a voluntary basis, the Musical Upbringing University was established embraced tens of organizations, where by forces of the music high school, concerts were performed regularly. Semion Grigoryevich was very proud of both pianos installed in his initiative in every workshop of the metallurgical complex and performances of sent-by-ourmusic-high-school concert-brigades in front of plant workers. In short, in outward appearance, in Magnitogorsk, there existed all attributes of conducted large-scale musicaleducative work, culmination of which became annual regional and municipal Fests of Song.

However, by beginning of 80-ies, the wide-spread opulently advertized musicians' enlightening activity guided by Municipal Musical Upbringing University started fading. The music high school top-managers and direct chiefs of performing practice of students hardly could complete concert brigades for their concert performing trips to enterprises and educational institutions of the town. More and more often, students and teachers refused performing and they had weighty reasons for it. Musicians required really not much: a piano should be in a working order and, in the middle of the performances, listeners should not speak, smoke or laugh. Otherwise, musicians refused making the concert trips. But local events organizers burdened with not less complicated problems could not ensure even this minimum of conditions. Listeners were in working coveralls after a working shift, dirty and tired - they refused listening music during 45 minutes; the music by Bach or Beethoven was difficult for their understanding and besides, it was performed by a musician-beginner (of course, there happened cases of mistakes in text, stoppages and repetitions from the very beginning).

In short, a crisis situation of a kind was formed: leaders of both parties, as the saying puts it, made a pressure on people, "You will perform" _ "You will listen". Being unsatisfied with each other, both musicians and listeners found various reasons for not taking part in such events.

\section{DEVELOPING THE COMPREHENDING OF THE ESSENCE OF A PROBLEM}

When the new mangers' team accumulated enough of vigor in order to form a sober estimation of real results of our impact on masses, it was discovered that musicians' coefficient of efficiency (if to put it mildly) was not high. The most important conclusion: most evidently, practice did not confirm the idea that our concerts stimulated a listenerbeginner for a more intensive consumption of high art. With a disappointment, musicians acknowledged that in concert halls - even on concerts of the chapel choir, which was the only professional group in the town - more often than not, a present listeners' number was less than that of performers on a stage. For example, the chapel choir concert taking place in 1975 on the occasion of opening of the concert hall of Magnitogorsk's music high school containing 500 seats collected not more than 40 listeners.

More and more facts convinced us that the expected urban population's contagiousness by music did not come true - a listener came to a concert hall not in answering the call of his heart. This was the first problem making us to interpret critically what was going on. During grounds examination of the metallurgical complex, where our concerts took place, we discovered that $90 \%$ instruments (pianos and somewhere even grand pianos) were not suitable for performing a music: on ones, a key was absent, others were absolutely not tuned, third ones were even dismounted - it was impossible to perform even a childish song on them leaving alone masterpieces by Chopin.

For one gazing at listeners' faces, it used to be just easy as a piece of cake to notice their indifference to a stage: during performance, suddenly, they used to get up and go away ostentatiously speaking in a high key - For them, it was just an obligation. As for the local fests of song, they were conducted in a rather strange mode: a quantity of singing people, who were collected by an arbitrary decision of the municipal administration, was sufficient, while listeners were almost absent at all. People sang for themselves. One could say that this is good; after all, the essence of a fest of song consists in collecting a crowd and making it to sing: there must not be pure listeners. But more often than not, by local organizers, people were brought to the fests, which not only did not sing but even did not know, what they should sing. In such cases, S.G. Eidinov got nervous very much but kept insisting, "That is just organizational shortages; I see them and am trying to overcome". As many other creative people, he had an intrinsic characteristic of his nature consisting in receiving a joy from the process itself. He saw his role in a romantic light not corresponding to the real state of things.

Me, too, since I became director of the music high school, I was carried away by the enthusiasm of the educative work via my active involvement in this marathon and using forms worked-out by Eidinov. Non-negligible efforts were dedicated to the work on improvement of the activity organization and performances quality enhancement: pianos and grand pianos were put by us in order; necessary minimum of stage and hall preparation to concerts was ensured; with organizers of production-related concert grounds, conditions were agreed in detail of concerts performances and listeners collection. At first, it seemed that the measures taken were able to induce a new breath to the educative work; but soon it came to be understood that it was just self-deception, complacency by process, and nothing more - The situation repeated itself (as the saying puts it) as like as two peas.

As we failed in the area of improvement of traditional work forms, we tended introducing new forms of the musical educative activities: we established Folk Conservatory (individual free-of-charge education of working youth) and Museum of town's musical culture; we concluded an agreement with Composers' Union of Russia; and during ten years by creative forces of local musicians regularly, we conducted concerts containing masterpieces of famous composers. Many of the latter started to be invited by us to our fests of song.

A numerical strength of song fests participants was expanded to really gigantic sizes. For example, the last 
Municipal Fest of Song (1986) arranged at the monument by sculptor L.N. Golovnitsky "Rearward area's contribution to Front" counted 17 thousand singers. For participation in it, there was invited the famous composer D.B. Kabalevsky, an icon in the sphere of musical educative work. We cherish a hope to improve the present situation cardinally.

To the fest, there was conducted especially scrupulous preparation: half-year before its conduct, we approved repertoire and distributed records of notes, appointed responsible conductors-synchronists. ${ }^{l}$ The municipal authorities issued a decree obligating all heads of amateurish choirs to conduct a thorough preparation. Forces involved were not small. For example, there were conducted several meetings of organizing committee with attendance of heads of education departments, managers of professional music high schools; there were distributed concrete tasks; etc. With a purpose of quality improvement of music performance, for a role of song precentors, there were invited good singers from the town's professional chapel choir, vocal ensembles of our music high school and other professional singers. In other words, everything was thought out and prescribed to the last detail.

\section{ENLIGHTENMENT AFTER DISAPPOINTMENT}

The grandiose Fest of Song was visited by as many listeners as never before. Until now, this magnificent picture stays in my eyes. The participants moved to the Monument by three columns, five to seven thousand people in each. Impressive sight!

There was accomplished a system of measures on improvement of organizational part of the event: For the main orchestra conductor, a platform was built 5 meters high with spiral stairs, while for precentors, special podiums were envisaged. There was produced a symbolic Song Fest Key cast from stainless steel. On the fest opening ceremony, this key was handed over to D.B. Kabalevsky as the honorary guest. In outward appearance, everything was very triumphant and powerful.

Notwithstanding, later on, a thought came that there was nothing to be especially proud of: people came to this fest not of their own will and instead, because they were made to do it - At the moment of the fest opening ceremony, when to the audience, Dmitry Borisovich Kabalevsky was introduced, I noticed that it looked like as flanks of our huge hill, where thousands of participants were located, started fusing - the reason was that participants started dispersing from there. Police tried to fasten the cordon as (apparently by portable radio sets) there was given the command "Detain people!" But it is impossible to stop such people's crowd, is not it The rest audience spoke non-stop and fooled around with their backs to the concert ground.

At archives, there remained photographs of this fest bearing evidences of the large scale of the event. On one hand, one might be proud that successfully there was

${ }^{1}$ During a crowded fest, at a music-rack, as a rule, one conductor used to stand, while synchronists-conductors used to stand in a visible distance from him and copied his every gesture. collected such quantity of people. On the other hand, it is impossible to chase away a realization that even so large scale action did not become a true cultural achievement or even a noticeable event in the musical life.

A curious case remained in the memory. It took place by the end of the fest. D.B. Kabalevsky stood at a grand piano, sound of which was enhanced by microphones, and looked proudly at the people's crowd - His songs were sung by 17 thousand people at the same time. Suddenly a boy ran to him and asked for his autograph; and willingly, Kabalevsky put his signature on a songbook cover. Such songbooks were at hands of all children and many of them decided that it was a chance to obtain his autograph.

The crowd counted several thousands of children dashed to Kabalevsky and transformed itself into an avalanche. Being afraid for the life of 80-years-old Dmitry Borisovich, I lifted him by my arms and rushed in direction of the river, where our official car stood. As soon as the driver saw us, he opened the door and let me a chance of literally pushing Kabalevsky on the rear seat. The crowd surrounded the car but already the celebrity was beyond an access. Afterwards, Dmitry Borisovich gratified me being astonished, how it was possible that I had enough forces to run up with him on my arms to the car. After all, he was about two meters high.

Being a bright interesting person, D.B. Kabalevsky made a strong impression on those, who entered into a communication with him. In musical-educative circles, he was known as an author of a system of schoolchildren's musical upbringing distinct with a lot of advantages and (what was the most important thing) with a well-thought-out program of music lessons conduct from $1^{\text {st }}$ to $8^{\text {th }}$ grades of general education school. The second serious achievement of Kabalevsky was issuing of methodical and audio-training aids performing schoolchildren's acquaintance with masterpieces of symphonic, vocal, choral and chamberinstrumental music. He succeeded in elevating of educational level of music lessons givers, who gained a chance of improving their qualification, of better mastering their instruments, of deeper knowing the music history and musical literature. Thus, in a work with schoolchildren, the program relied on musicians-professionals.

A weak link of the system was the fact that during the lessons, children did not make music themselves, because of which feature the studies were transformed into purely cognitive exercise, where a pupil - as if he was a vessel was filled up with information on the music. But unfortunately, Kabalevsky was stubborn and kept away from a thought that he could mistaken. In that period of time, among choir heads, very popular was the methodic by D.E. Ogorodnov, which sometimes was called methodic of Russian bel canto. Unlike D.B. Kabalevsky with his system, its author taught children singing in a beautiful and impressive way - both in a choir and solo. On his lessons, children not only made music themselves but also were occupied with artistic recital, poems loud reading, etc. Ogorodnov needed assistance in his method popularization. However, Dmitry Borisovich stayed ultimatistic in relation of initiatives that were inconsistent with the developed by 
him system. He did not help to D.E. Ogorodnov, although he should do it as he was a deputy of the country's Parliament. In the similar way, (not without an advantage for himself), right off the bat, Kabalevsky rejected an alternative program developed by the sector of music of the scientific-research institute of art upbringing at Academy of pedagogical sciences, which accumulated the world experience of musical upbringing of children in $\mathrm{XX}^{\text {th }}$ century.

\section{FORMATION OF NEW VIEWPOINTS}

Let us return to the described event. When the fest was over, I mused for a long time that the way, which we stuck for all these years to, stayed to be a road to nowhere. Children taking part on the fest or other educative events became neither nobler nor more delicate in their souls. Both in form and in content, evidently, the conducted educative activities of the kind did not correspond to the spirit of times. The folk conservatory was in disfavor, for attending concerts of visitant composers, mainly, professional musicians came In general, as before, Magnitogorsk's residents stayed far from classical music - I studied literature related to musical enlightenment, in particular, works by B.V. Asafyev, vexing my mind in endeavors to find answers to our knotty questions. It turned out that even in the capital, where there was no shortage in professional players, nobody knows why, people were far from starving for a creative communication with musicians, and everything was unfolded not the way it was planned. Asafyev stated, "Populace stayed beyond music". It appeared to me that a possible cause consisted in an absence of interestedness from part of musicians themselves.

The conclusion offered itself: at the educative activities, it was necessary to rely on people, who were rare and possessed both extraordinary creative talent and enthusiasm. An "enlightenment" work conducted by forces of students of music high school or musical schools, after that they worked out their poor skills on several musical pieces, did harm as deformed listeners' notion about classical music. After such so-called "concerts", in their naivety, many believed that indeed they experienced a connection with the high music. It was not important for them at all that they were not captured by it, their souls made no work and hearts did not catch fire of interest. Such "enlightenment" was a typical profanation.

Finally as a result of long reflections (after all, Magnitogorsk's musicians were obsessed with the idea of the educative activities), we gained a foothold in the opinion that energy and efforts of musicians were necessary to be redirected on increasing level of professional education. Thus, the idea came to mind about necessity of establishment of higher musical educational institution in Magnitogorsk. The gradually taking shape conception of the musical institute based on the consideration that in a case of personnel arrival of a higher level, a stepwise level increase of the town's musical culture would become possible. In a business-area, a dilemma exists based on quite sophisticated question: What is primary: demand or supply? The same in music: we proceeded from the consideration that upon condition of formation of a squad of talented and competent musicians in Magnitogorsk, by their supply, they would be able to boost demand on the classical music.

On the common meeting of the music high school personnel, I outlined my views on a necessity of a higher educational institution establishment (a musical institute). Otherwise, we shall continue preparing specialists not really needed; after all, evidently, the secondary musical education as a social institution was devaluated; our society got satiated with specialists of this level — Today, more prepared musicians are needed, with a higher musical education.

It seemed, the music high school personnel accepted the idea with some skepticism. A considerable part of teachers looked at my "projects" with an evident disbelief — as if they said silently "it doesn't hurt to dream!" To my colleagues' credit, it should be said, among them, there were musicians, who started reckoning loudly on this and other not simple topics: why does a methodic work go on so badly; what prospects a music high school development has got; what awaits for our educates in their real life; etc.

As a result, the meeting came to a collective perception of necessity of moving in a direction of cardinal improvement of musical education. So we took a course for the institute establishment and changing of the urban culture infrastructure in direction of development of a network of professional art institutions.

\section{CONCLUSION}

Traditions - if they are genuine-are to be carefully preserved. But one should not mix traditional forms of work with the traditions themselves. As for forms of work, well, they are not a sacred cow. They require a constant renewal!

One should not forget that creative people are inclined to overestimation of their activities results. A task of a manager consists not in correcting them but instead in learning to objective estimation of a situation and activities results.

Manager is obliged thinking in a critical way.

In order to understand a problem, it is necessary to whack in details. Both in a management and in art — saying by words by Michael Chekhov, the actor - there rules the great "a little bit".

A manager's strength is in his ability to reach personnel's support of his ideas.

Some useful advices for managers-beginners:

- It is important to learn how to appreciate colleagues' critical sayings and give them scrupulous analysis.

- It's a bad practice to see enemies in people, who criticize you. People are not more stupid than you also they have constructive ideas.

- A critical rhetoric without layout of constructive proposals is perceived by people as growling of a person dissatisfied with the life. 


\section{REFERENCES}

[1] Cameron, Kim S., Quinn, Robert E. Diagnosing and Changing Organizational Culture, Addison-Wesley, 2001.

[2] Mintzberg, H. Structure in Five, Prentice/Hall International, Inc., 2002.

[3] Tulchinsky, G.L., Shekova, E.L. Cultural Management: Textbook, Lan, 2013.

[4] Korotkov, E.M. Administrating the Quality of Education. M., 2007. 